$\begin{array}{r}\text { Phinisi Integration Review } \\ \text { Vol. 1, No.2, Agustus 2018 Hal 201-207 } \\ \text { Website: http://ojs.unm.ac.id/pir } \\ \text { p-ISSN: 2614-2325 dan e-ISSN: 2614-2317 } \\ \hline\end{array}$

\title{
Vape Sebagai Gaya Hidup Komsumtif Baru Di Masyarakat
}

\author{
Dody Bimantara Marsigit \\ Fakultas Ilmu Sosial Dan Ilmu Politik, Universitas Indonesia \\ Email: dodybimantara@gmail.com
}

\begin{abstract}
The development of the era of modernization grows in line with the rapid development of lifestyle. Generally the development of lifestyle is in demand by urban communities, but with the many products make urban communities interested in the development of lifestyle so that this impact on behavioral patterns komsumtif society. as well as Vape or commonly referred to as Electric Cigarettes, is now developing and a choice of alternative smoking in the community, Serve healthier than conventional cigarettes, This is one reason why Vape quickly developed in Indonesia. Beginning with the many uses of Vape in the community, as well as the number of Vape sales shops in Indonesia, it is because of the research about lifestyle use of Vape among the community. This study uses qualitative methods, data collection techniques in this study are in-depth interviews and observation. The research theory used by the author is Consumtive Lifestyle Theory. The results obtained from this study is the lifestyle changes vape formed by the development of social development in society and Vape dikomsumsi not only seen from the value of the course but there will be 'mark value' in it.
\end{abstract}

Keywords: Society, Vape, Lifestyle, Compulsive Behavior.

\begin{abstract}
Abstrak. Perkembangan era modernisasi tumbuh seiring dengan pesatnya perkembangan gaya hidup. Umumnya perkembangan gaya hidup diminati oleh masyarakat perkotaan, namun dengan banyaknya produk membuat masyarakat perkotaan tertarik dengan perkembangan gaya hidup sehingga ini berdampak pada pola perilaku komsumtif masyarakat. sama halnya Vapeatau biasa disebutdengan Rokok Elektrik, kini berkembang dan menjadi pilihan alternatif merokok di masyarakat,Menjajikan lebih sehat dibandingkan dengan rokok konvensional, Hal ini menjadisalah satu alasan mengapa Vape cepat berkembang di Indonesia. Diawali dengan banyaknya penggunaan Vape di masyarakat, serta banyaknya toko - toko penjualan Vape di Indonesia, oleh karna itu dilakukan penelitian tentang gaya hidup pengguanaan Vape dikalangan masyarakat. Penelitian ini menggunakan metode kualitatif, teknik pengumpulan data dalam penelitian ini yaitu wawancara secara mendalam dan observasi. Teori penelitian yang digunakan oleh penulis adalah Teori Gaya Hidup Konsumtif. Hasil yang didapat dari penelitian ini adalah perubahan gaya hidup pengguanaan Vape terbentuk di sebabkan oleh perkembangan Sosial di masyarakat dan juga Vape dikomsumsi bukan hanya dilihat dari nilai gunanya saja akan tetapi ada ' nilai tanda' didalamnya.
\end{abstract}

Kata Kunci: Masyarakat, Vape, Gaya hidup, Perilaku komsumtif.

Ini adalah artikel dengan akses terbuka dibawah licenci CC BY-NC-4.0

(https://creativecommons.org/licenses/by-nc/4.0/) 
Phinisi Integration Review. Vol 1(2) Agustus 2018

\section{PENDAHULUAN}

Masyarakat Indonesia yang khususnya berada di perkotaaan memiliki perkembangan gaya hidup, hal ini dikarenakan produk yang terus berkembang mudah didapatkan di kota besar. Perkembangan gaya hidup yang pesat pada perkotaan bisa dilihat dengan banyaknya pusat perbelanjaan yang berdiri di perkotaan. Banyaknya pusat perbelanjaan yang berdiri pada kota besar membuat masyarakat penikmat perkembangan gaya hidup semakin antusias. Namun perkembangan gaya hidup tersebut dapat dikhawatirkan karena dapat membuat seseorang mengkomsusmsi barang-barang yang tidak mementingkan fungsi dari barang tersebut namun hanya untuk memenuhi hasrat yang dimiliki.

Saat ini perusahaan fokus pada bidang gaya hidup yang diperuntukkan pada kalangan pria. Produk yang diperuntuk oleh kalangan pria, membuat pria saat ini tertarik untuk mengikuti perkembangan gaya hidup yang ada. Saat ini dikalangan pria khususnya anak muda sedang diramaikan dengan adanya Vape adalah sebuah elektronik yang membuat liquid diubah menjadi uap. Penggunaan Vape dalam kalangan masyarakat ini sangat marak, sebagaian besar pengguna Vape berasal dari orang-orang perokok yang hijrah menjadi penggemar Vape. Sebagian orang mengatakan bahwa Vape dapat membuat kecanduan perokok dapat hilang, serta resiko yang lebih sedikit, para remaja misalnya remaja ini sangat menunjukkan bahwa dirinya selalu mengikuti jaman yang terus berkembang.

Salah satu kota besar yang masyarakatnnya tertarik menjadi pengguna Vape adalah kota Bekasi, Jawa barat di mana bekasi sebagai salah satu kota Industri yang besar di Indonesia yang memiliki sarana fasilitas yang lengkap, perkembangan kota cukup pesat terlihat dari banyaknya berdiri pusat perbelanjaan, sarana hiburan, dan juga mulai bermunculannya sarana tempat bersosialisasi baru yaitu mulai maraknya café dan juga tempat bersantai untuk bersosialisasi yang beragam. Faktor ini juga memicu dengan berkembangnya Vape di kota Bekasi Vape sangat menarik kalangan masyarakat untuk mencoba memiliki. Namun selain dikalangan masyarakat, para pekerja juga menikmati dan mengikuti dengan adanya Vape. Oleh sebab itu toko Vape saat ini juga mulai bermunculan dan beragam, bahkan saat ini menjadi tempat yang sangat sering dikunjungi disaat waktu luang dengan alasan agar mereka dapat mengerti dalam menggunakan Vape dengan baik. Dengan hal ini munculah fenomena Masyarakat pengguna Vape yang baiasanya berbentuk komunitas yang sangat beragam.

Vape di ranah internasional sudah cukup lama terkenal. Sebelum maraknya dengan adanya Vape ini, awalnya Vape berasal dari rokok elektrik (e-ciggarete). Pencetus Vape ini berasal dari china yang bernama Hon Lik. Pada tahun 2000 Hon Lik memiliki ide membuat rokok elektrik, dan pada tahun 2003 Hon Lik berhasil membuat rokok elektrik atau Vape. Dengan cepat Vape beredar di masyarakat Bangkok. Setelah Vape sangat digemari di masyarakat Bangkok pada tahun 2007 Vape menarik masyarakat Amerika untuk mengkomsumsi. Dan pada tahun 2013 sampai sekarang Vape sudah menarik masyarakat Indonesia untuk mengkomsumsi, namun sampai saat ini belum ada regulasi serta sertifikat legal dari Badan Pengawas Obat dan Makanan (BPOM) mengenai aturan penggunaan vape termasuk cairan liquid yang digunakan dan saat sudah marak beredar, walaupun saat ini pemerintah tengah mendalami aturan mengenai cukai rokok elektrik dan juga cairan (liquid) (https://www.viva.co.id/gaya-hidup/kesehatanintim/880452-bpom-indonesia-belum-punyaregulasi-edar-vape).

Vape atau bisa disebut dengan Vapor memang muncul sebagai alternatif pengganti rokok konvensional (tembakau), tapi bukan semata-mata hanya digunakan oleh yang dulunya perokok saja. Menurut penelitian dari Ernst \& Young (2016: 6), berkembang atau semakin bertambahnya para pengguna Vape tidak hanya yang dulunya merokok saja tapi ada juga yang bukan perokok atau bahkan tidak pernah merokok, sekarang ikut menggunakan Vape, seperti data dalam tabel berikut: 
Figure 4: E-cigarette users by tobacco smoking characteristics (percentage of users), $2015^{9}$

\begin{tabular}{|c|c|c|c|c|c|c|c|c|c|}
\hline Country & \multicolumn{3}{|c|}{ Dual user } & \multicolumn{3}{|c|}{ Ex-smoker } & \multicolumn{3}{|c|}{ Never smoked } \\
\hline All & $64 \%$ & $59 \%$ & $54 \%$ & $31 \%$ & $37 \%$ & $37 \%$ & $5 \%$ & $4 \%$ & $9 \%$ \\
\hline France & $51 \%$ & $44 \%$ & $50 \%$ & $41 \%$ & $50 \%$ & $38 \%$ & $9 \%$ & $6 \%$ & $11 \%$ \\
\hline Germany & $70 \%$ & $57 \%$ & $58 \%$ & $25 \%$ & $37 \%$ & $35 \%$ & $5 \%$ & $5 \%$ & $7 \%$ \\
\hline UK & $62 \%$ & $61 \%$ & $44 \%$ & $35 \%$ & $33 \%$ & $35 \%$ & $3 \%$ & $6 \%$ & $20 \%$ \\
\hline Russia & $71 \%$ & $74 \%$ & $70 \%$ & $28 \%$ & $25 \%$ & $22 \%$ & $1 \%$ & $1 \%$ & $7 \%$ \\
\hline South Korea & $\# \mathrm{~N} / \mathrm{A}$ & $79 \%$ & $34 \%$ & $\# N / A$ & $20 \%$ & $60 \%$ & $\# \mathrm{~N} / \mathrm{A}$ & $1 \%$ & $6 \%$ \\
\hline
\end{tabular}

Source: Kantar, EY analysis

${ }^{*}$ All refers to the seven countries surveyed

Tabel diatas menunjukkan kalau ada 3 macam kategori pengguna Vape atau Vapor, yang pertama (1) Dual User dimana dirinya menggunakan Vape tapi masih juga merokok konvensional. Kedua (2) Ex-smoker adalah mantan perokok tembakau yang sekarang beralih ke Vape, dan ketiga (3) Never Smoked yang memang bukan perokok dan belum pernah merokok sama sekali, tetapi sekarang menggunakan Vape.

Banyaknya peminat vape di masyarakat perkotaan serta banyaknya toko penyedia perlengkapan vape, membuat pemilik toko harus memiliki strategi untuk menarik pelanggan demi mendapatkan keuntungan yang banyak. Seperti misalnya APVI (Asosiasi Personal Vape Indonesia), atau Komunitas yang terbentuk yang mereka beri merek dagang toko seperti "Vapemorfosis" yang ada di Bekasi, Jawa Barat. Mereka memanfaatkan perkembangan media sosial yang ada dan digunakan sebagai alat pemasaran mereka, contohnya menggunakan Instagram. Pemilik toko akan memberikan barang dagangannya kepada pemilik akun yang banyak memiliki pengikut yang cukup banyak di Instagram, setelah itu pemilik mengunggah dengan memberikan deskripsi tentang toko tersebut. Selain itu dengan memasang dan juga membagikan brosur dijalan umum yang banyak dilewati masyarakat. Didalam spanduk itu berkalimat-kalimat yang membuat pengguna setia vape tertarik seperti " 20 pengunjung pertama mendapatkan coiling gratis" atau "discount $20 \%$ untuk pembelian 250rb ke atas" dan ada juga strategi pemasaran lain dengan menyediakan banyak model dan bentuk namun mereka menjual dengan harga cukup tinggi dengan perbedaan selisih yang cukup besar, dan ada juga yang hanya memiliki banyak pilihan varian perlengkapan vape namun memberikan harga yang terbilang murah dengan perbedaan selisih yang cukup besar pula.

Penulis dalam hal ini memilih penelitian ini untuk mengungkap gaya hidup yang ada dikalangan masyarakat yang berada di Indonesia terkhusus di kota Bekasi, jawa barat. Maka dalam penelitian ini akan dilakukan penelitian untuk mengugkapkan terbentuknya gaya hidup pada kalangan masyarakat perkotaan di kota Bekasi, Jawa barat, yang dilihat dari masyarakat pengguna Vape.

Pokok permasalahan yang akan dikaji adalah mengetahui penyebab gaya hidup masyarakat pengguna vape, serta mengetahui penyebab dan gaya hidup masyarakat pengguna vape dikota besar. Manusia adalah makhluk sosial, dalam kehidupannya selalu membutuhkan makhluk lain. Dalam hal ini faktor sosial budaya merupaka kekuatan yang paling besar untuk mempengaruhi seseorang untuk berprilaku komsumtif. Kehidupan masyarakat pastinya tidak lepas dari prilaku dan pola hidup lingkungan sekitarnya. Memenuhi kebutuhan untuk mengkomsumsi vape misalnya pada kehidupan sehari-hari membuat seseorang terbiasa akan hal tersebut.

Teori yang akan digunakan dalam menganalisis penelitian ini adalah teori gaya hidup komsumtif. Teori gaya hidup komsumtif adalah suatu perilaku yang tidak lagi didasarkan pada pertimbangan yang rasional, melainkan membeli produk atau jasa tertentu untuk memperoleh kesenangan atau hanya perasaan emosi, Minor dan Mowen (2002) 
Phinisi Integration Review. Vol 1(2) Agustus 2018

"ketika gaya menjadi segala-galanya dan segala-galanya menjadi gaya, maka perubahan penampilan dan citra diri juga akan masuk dalam permainan komsumsi" Chaney (2003: 20).

Fenomena yang berkembang di perkotaan khususnya dikalangan masyarakat sangatlah menarik untuk dibahas.perkembangan perilaku gaya hidup komsumtif ini diterima bagi sebagian masyarakat. Menurut sebagian masyarakat perilaku komsumtif saat ini tidak melihat dari barang mereka beli memiliki manfaat yang besar melainkan hanya memenuhi gaya hidup, karena hal tersebut membuat seseorang menjadi boros untuk hal-hal yang tidak terlalu penting. Namun dengan terus berkembangnya produk yang bermunculan pada era sekarang ini membuat perilaku komsumtif di kalangan masyarakat menjadi penasaran dan membuat mereka tertarik untuk menjadi komsumtif. Hal tersebut yang membuat masyarakat terutama seseorang itu memiliki perilaku komsumtif.

\section{METODE}

Metode penelitian merupakan seperangkat cara yang digunakan untuk melakukan penelitian yang dilaksanakan dalam penelitian ini sendiri terdapat banyak metode yang dapat digunakan namun dalam penelitian ini menggunakan metode penelitian kualitatif.

Penelitian ini akan memfokuskan pada meluas dan maraknya komunitas-komunitas penyedia vape dan juga pengguna vape di salah satu komunitas pengguna vape di kota Bekasi, Jawa barat, dimana mereka memiliki ketertarikan terhadap perkembangan gaya hidup yang ada didunia. Dimana saat ini masyarakat memiliki ketertarikan gaya hidup sedang digemparkan dengan produk yang diminati dimasyarakat terutama dikalangan remaja yaitu Vape. Dengan metedo kualitatif, peneliti mendapatkan data dari individu yang mengetahui mengenai fokus penelitian agar dapat membantu penulis untuk mengetahui permasalahan dan menyelesaikan penulisan.

\section{TEMUAN DAN ANALISIS}

Perkembangan gaya hidup saat ini memang sangat pesat membuat sebagian masyarakat Indonesia saat ini sangat mengikuti perkembangan gaya hidup.hal tersebut tumbuh seiring dengan perkembangan gaya hidup yang menjamur di Indonesia. Munculnya pusat perbelanjaan atau shooping mall, industry mode, dsb. Sama halnya dengan toko-toko vape, mulai maraknya toko vape yang ada juga tumbuh sejalan dengan bermunculannya komunitas pengguna vape. Banyaknya masyarakat di Indonesia khususnya di Bekasi, Jawa barat membuat industri-industri yang mengeluti bidang ini juga bersaing untuk membuat beragam jenis model dan merek guna menarik peminat masyarakat. Hal ini sejalan dengan perkembangan jaman yang hanya mementingakan perilaku gaya hidup bahkan penampilan menjadi hal utama.

Budaya Konsumen adalah budaya yang dilakukan oleh konsumen itu sendiri. Budaya Konsumen menggunakan gambaran atau image, tanda, dan benda simbolik yang mengumpulkan mimpi, keinginan dan fantasi yang menegaskan keaslian dan pemenuhan emosional menyenangkan diri sendiri bukan orang lain. Gaya Hidup menunjukkan bagaimana individu mengatur kehidupannya, baik kehidupan pribadi, kehidupan bermasyarakat, perilaku didepan umum, dan upaya membedakan statusnya dari orang lain melalui simbol-simbol (Nadia, 2017:

11). Perbedaan itu bisa dilihat dari cara berpakaiannya, pemilihan kata-kata saat berbicara, kendaraan, rumah, dsb. Hal-hal tersebut menunjukkan Gaya Hidup dalam konteks budaya Konsumsi memiliki arti individualitas, ekspresi diri, dan kesadaran diri untuk bergaya (Featherstone, 2007).

Gaya hidup merupakan ciri sebuah dunia modern, atau yang biasa disebut dengan modernitas. Maksudnya adalah siapapun yang hidup dalam masyarakat modern menggunakan gagasan tentang gaya hidup untuk menggambarkan diri sendiri maupun orang lain. Bisa kita kaitkan bahwa kehidupan saat ini lebih mementingkan menggunakan atau membeli sebuah produk gaya hidup untuk menunjukkan strata kelasnya bahwa seseorang yang mengikuti perkembangan jaman tanpa melihat lagi kegunaan produk tersebut. Seperti halnya vape yang juga belum memiliki legalitas pengunaan di Indonesia dan belum memiliki bukti konkret bahwa vape lebih sehat untuk dikomsumsi dibandingkan rokok konvensional menunjukkan bahwa masyarakat saat ini tidak memperhatikan dampak selanjutnya dalam mengkomsumsi sesuatu untuk tubuhnya namun hanya memperhatikan penampilan yang mereka miliki ini menunjukkan salah satu ciri bagaimana prilaku gaya hidup komsumtif. 
Penulis akan menjelaskan mengenai bagaimana perkembangan gaya hidup saat ini dan membentuk sebuah kebudayaan baru dalam masyarakat perkotaan, dimana suatu kebudayaan dapat terbentuk karna kebiasaan yang terus menerus dilakukan oleh masyarakat, suatu kebiasaann dapat terbentuk karena adanya sistem sosial yaitu, aktifitas-aktifitas manusia yang berinteraksi, berhubungan serta bergaul satu sama lain, ini berkaitan juga bagaiman seseorang mengkomsumsi sesautu barang atau alat dikarenakan bukan karena manfaaatnya namun karna ada "nilai tanda" didalamnya.

Pada era modernisasi gaya hidup tumbuh dengan sangat cepat. Hal itu dapat terjadi karena industry dalam bidang gaya hidup selalu memberikan produk yang selalu mengikuti jaman. Selalu memberikan produk yang mengikuti perkembangan jaman ini tumbuh beriringan sejalan dengan teknologi yang terus berkembang, yang mana teknologi tersebut digunakan untuk pemasaran suatu produk agar dapat membuat daya Tarik masyarakat terhadap produk tersebut bertambah.

Gaya hidup adalah pola-pola tindakan yang membedakan antara satu orang dengan yang lain (chaney :1996). Maksudnya adalah siapapun yang hidup dalam masyarakat modern akan menggunakan gagasan tentang gaya hidup untuk menggambarkan tindakan sendiri maupun orang lain. Perkembangan gaya hidup yang ada pada saat ini sebenarnya memiliki dampak yang baik untuk sesorang terutama masyarakat luas untuk menjadi lebih baik. Namun apabila seseorang tersebut tidak dapat mengaplikasikan dengan baik maka akan bedampak buruk bagi dirinya.

Vape adalah salah satu perkembangan elektronik yang sangat fenomenal di kalangan masyarakat, alat ini dapat menghasilkan alairan listrik yang diubah menjadi panas kemudian membuat cairan menjadi gas dimana akan mengeluarkan uap atau asap singkatnya alat ini biasa disebut rokok elektrik. Memang vape adalah sebuah peningkatan yang versi yang berasal dari rokok elektrik. Peningkatan yang diberikan ini di lihat dari chipset yang ditanamkan dalam sebuah mod. Chipset yang ditanamkan memiliki 3 jenis yaitu YiHi, DNA, dam Standart, 3 jenis chipset tersebut memiliki masing-masing perbedaan yang dapat digunakan sesuai selera dari pengguna. Selain itu, masingmasing chipset ini memiliki kelebihan dan kekurangannya tersendiri. YiHi misalnya adalah sebuah chipset yang berasal dari china yang

\section{Marsigit. Vape sebagai gaya hidup}

memiliki kelebihan dapat menghasilkan panas yang cepat, sedangkan DNA yang berasal dari Amerika memiliki kelebihan menghasilkan panas yang stabil, dan untuk chipset standard tidak memiliki kelebihan apapun disbanding YiHi dan DNA. Vape sendiri terdiri dari berbagai perangkat yaitu: mod, driptip, Atomizer, Coil/Kawat, Wick/sumbu/kapas, baterai dan yang paling utama adalah Liqud/cairan.

Penyebab seseorang dapat tertarik terhadap gaya hidup memiliki 2 hal yang mempengaruhi, yaitu dari factor external dan internal. Factor external dimana lingkup pergaulan bisa menjadi sebab seseorang dapat tertarik selain itu teman dan juga rekan sebaya mereka. Lalu, factor internal adalah pengalaman yang mereka miliki berdasarkan pengamatan, persepsi, dan melalui teknologi yang seseorang gunakan bahkan dapat mempengaruhinya. Seseorang bahkan yang berada dalam suatu komunitas masyarakat contohnya, dia dipengaruhi oleh lingkup pergaulan yang ada disekitar mereka. Seseorang pengguna vape dalam lingkungan komunitas memilki beberapa kategori yang membuat mereka tertarik untuk menggunakan vape.

Menjadi masyarakat pengguna pasti mememiliki alasan tersendiri, sama halnya seseorang anggota komunitas disalah satu komunitas kecil pengguna vape yang ada di kota Bekasi, Jawa barat. Setiap anggota komunitas memiliki alasan dan tujuan pribadi yang membuat mereka tertarik untuk menjadi pengguna vape. Alasan dan tujuan anggota komunitas menjadi pengguna vape ada 5 faktor alasan yang berbeda-beda.

Pertama membuat pengguna dapat mengikuti perkembangan gaya hidup pada saat ini. Anggota dikomunitas yang mengikuti perkembangan gaya hidup ini dapat memiliki nilai lebih atau nilai sosial lebih dibandingkan anggota lainnya.

Kedua adalah uap vape dapat dibentuk dengan sedemikian rupa untuk menghasilkan bentuk yang unik. Selain dapat menghasilkan bentuk yang unik vape menjadi sebuah seni baru dengan membentuk uap tersebut, dan memiliki daya Tarik seseorang untuk mencoba.

Ketiga yaitu vape dipercaya dapat menghilangkan kecanduan terhadap rokok konvensional dan memiliki resiko lebih kurang terhadap penyakit bila dibandingkan rokok konvensional, dengan dampak positif itu menjadi alasan seseorang dalam masyarakat dapat tertarik 
Phinisi Integration Review. Vol 1(2) Agustus 2018

untuk menjadi pengguna vape. Namun hal ini belum ada penjelasan medis untuk hal ini.

Ke empat pengguna tertarik terhadap uap yang dihasilkan oleh vape sangat banyak dibandingkan rokok konvensional.

Ke lima vape memiliki rasa yang bervariasi yang bisa disesuaikan dengan selera atau keinginan pengguna.

\section{SIMPULAN DAN SARAN}

Perkembangan era modernisasi tumbuh seiring dengan pesatnya perkembangan gaya hidup. Umumnya perkembangan gaya hidup diminati oleh masyarakat perkotaan, namun dengan banyaknya produk membuat masyarakat perkotaan tertarik dengan perkembangan gaya hidup sehingga ini berdampak pada pola perilaku komsumtif masyarakat.

Dalam hal ini dikaitkan dengan Vape, yaitu salah satu produk rokok elektrik yang menjadi alternatif masyarakat terutama yang perokok. Banyak perusahaan memanfaatkan perkembangan konsumtif masyarakat kota dengan cara memperbanyak produksi barangbarang seperti vape. Demikian karena masyarakat Indonesia khususnya perkotaan memiliki perkembangan gaya hidup yang pesat.

Gaya hidup merupakan ciri sebuah dunia modern, atau yang biasa disebut dengan modernitas. Maksudnya adalah siapapun yang hidup dalam masyarakat modern menggunakan gagasan tentang gaya hidup untuk menggambarkan diri sendiri maupun orang lain. Bisa kita kaitkan bahwa kehidupan saat ini lebih mementingkan menggunakan atau membeli sebuah produk gaya hidup untuk menunjukkan strata kelasnya bahwa seseorang yang mengikuti perkembangan jaman tanpa melihat lagi kegunaan produk tersebut.

Dalam hal ini, peneilitian ini menyimpulkan bahwa, bukan hanya perokok yang bs berpindah ke rokok konvensional seperti vape, melainkan yang bukan perokok pun bs menggunakan vape. Dikarenakan gaya hidup, terutama gaya hidup daerah perkotaan yang cenderung konsumtif, menyebabkan masyarakat menggunakan vape.

Selain gaya hidup, budaya konsumen juga sangat mempengaruhi. Budaya Konsumen adalah budaya yang dilakukan oleh konsumen itu sendiri. Budaya Konsumen menggunakan gambaran atau image, tanda, dan benda simbolik yang mengumpulkan mimpi, keinginan dan fantasi yang menegaskan keaslian dan pemenuhan emosional menyenangkan diri sendiri bukan orang lain.

Vape adalah salah satu perkembangan elektronik yang sangat fenomenal di kalangan masyarakat, alat ini dapat menghasilkan alairan listrik yang diubah menjadi panas kemudian membuat cairan menjadi gas dimana akan mengeluarkan uap atau asap singkatnya alat ini biasa disebut rokok elektrik. vape adalah sebuah peningkatan yang versi yang berasal dari rokok elektrik. Peningkatan yang diberikan ini di lihat dari chipset yang ditanamkan dalam sebuah mod. Chipset yang ditanamkan memiliki 3 jenis yaitu YiHi, DNA, dam Standart, 3 jenis chipset tersebut memiliki masing-masing perbedaan yang dapat digunakan sesuai selera dari pengguna.

Penyebab seseorang dapat tertarik terhadap gaya hidup memiliki 2 hal yang mempengaruhi, yaitu dari factor external dan internal. Factor external dimana lingkup pergaulan bisa menjadi sebab seseorang dapat tertarik selain itu teman dan juga rekan sebaya mereka. Lalu, factor internal adalah pengalaman yang mereka miliki berdasarkan pengamatan, persepsi, dan melalui teknologi yang seseorang gunakan bahkan dapat mempengaruhinya. Seseorang bahkan yang berada dalam suatu komunitas masyarakat contohnya, dia dipengaruhi oleh lingkup pergaulan yang ada disekitar mereka.

Alasan dan tujuan anggota komunitas menjadi pengguna vape ada 5 faktor alasan yang berbedabeda, yaitu:

1) Membuat pengguna dapat mengikuti perkembangan gaya hidup pada saat ini. Anggota dikomunitas yang mengikuti perkembangan gaya hidup ini dapat memiliki nilai lebih atau nilai sosial lebih dibandingkan anggota lainnya.

2) Uap vape dapat dibentuk dengan sedemikian rupa untuk menghasilkan bentuk yang unik. Selain dapat menghasilkan bentuk yang unik vape menjadi sebuah seni baru dengan membentuk uap tersebut, dan memiliki daya Tarik seseorang untuk mencoba.

3) Vape dipercaya dapat menghilangkan kecanduan terhadap rokok konvensional dan memiliki resiko lebih kurang terhadap penyakit bila dibandingkan rokok konvensional, dengan dampak positif itu menjadi alasan seseorang dalam masyarakat dapat tertarik untuk menjadi pengguna vape. Namun hal ini belum ada penjelasan medis untuk hal ini. 
4) Pengguna tertarik terhadap uap yang dihasilkan oleh vape sangat banyak dibandingkan rokok konvensional.

5) Vape memiliki rasa yang bervariasi yang bisa disesuaikan dengan selera atau keinginan pengguna.

\section{DAFTAR RUJUKAN}

Clancy L (2004) Smoking ban can be health initiative of the century. Luke Clancy,chairperson of ASH Ireland, Press release, 18 February. Available at: http://www.ash.ie/News/Archived_ News_2004/Century, Diakses terakhir 12 Maret 2018, Pukul 23.41 WIB.

Fernandez, Eluska. 2016. No Smoke without Fire: Public Health, Morality, and the Civilized Self. Irish Journal of Sociology. SAGE Publication.

Ernst \& Young LLP. 2016. E-Cigarettes: an emerging category. Published in the UK.

Featherstone, Mike. 2007. Consumer Culture and Postmodernism Second Edition. SAGE Publications Ltd.

Gordon C. 1991. Govermental Rationality: An Introduction. In: Burchell G, Gordon C and Miller P (eds) The Foucault Effect: Studies in Govermental Rationality. Hemel Hempstead: Harvester Wheatsheaf. Pp. 1-51.

Holahan A (2003) Plan to ban smoking in pubs. Letter to the Editor, The Irish Times, 17 February.
Marsigit. Vape sebagai gaya hidup

Howell F (2005) Smoke-free bars in Ireland: A runaway success. Tobacco Control $14: 73-74$.

O'Brien PJ. 2004. Deasy in teh Dail Bar. Letter to the Editor. The Irish Times, 7 April.

O'Donnell S. 2004. Banning Smoking in Pubs. Letter to the Editor. The Irish Times. 14 July.

$\mathrm{O}^{\prime} \mathrm{Fa}^{\prime}$ tharta $\mathrm{C}$ (2014) Time to clear the air over use of e-cigarettes. Irish Examiner, 18 March.

Reilly J (2014) 10th Anniversary of the Workplace Smoking Ban in Ireland - Statement by Dr. James Reilly TD, Minister for Health, Media release of the Department of Health, Fernández $173 \quad 24$ March. Available at http://www.dohc.ie/press/releases/2 014/20140324.Diakses terakhir 12 Maret 2018, Pukul 23.41 WIB

Woods B. 2003. Smoking Ban in Pubs. Letter to the Editor, The Irish Times, 26 July.

https://www.bukalapak.com (Toko Online) Diakses terakhir: 7 Januari 2018, Pukul19.56 WIB

https://www.tokopedia.com (Toko Online) Diakses terakhir: 7 Januari 2018, Pukul19.56 WIB

https://www.apviofficial.com (Asosiasi Personal Vaporizer Indonesia)

https://www.tirto.id/bisnis-vapor-minus-payunghukum-bRXE Diakses terakhir: 8Februari 2018. Aditya Widya Putri (Bisnis Vapor Minus Payung Hukum) 